\title{
PENGARUH PEMBERIAN SUMBER NUTRIEN BERBEDA PADA MEDIA KULTUR TERHADAP KEPADATAN POPULASI DAN LAJU PERTUMBUHAN Daphnia sp.
}

\section{EFFECT OF DIFFERENT NUTRIENT RESOURCES IN CULTURE MEDIA ON POPULATION DENSITY AND GROWTH RATE of Daphnia sp.}

\author{
Dini Islama ${ }^{1}$, Nurhatijah ${ }^{1}$, M. Muntadhar ${ }^{1}$, Muhammad Fadhli ${ }^{2}$ \\ ${ }^{1}$ Program Studi Teknologi Produksi Benih dan Pakan Ikan, Politeknik Indonesia Venezuela (Poliven), \\ Jln. Bandara Sultan Iskandar Muda km 12, Blang Bintang, Aceh Besar, Aceh 23372 \\ ${ }^{2}$ Program Studi Teknologi Produksi Benih dan Pakan Ikan, Politeknik Indonesia Venezuela (Poliven), \\ Jln. Bandara Sultan Iskandar Muda km 12, Blang Bintang, Aceh Besar, Aceh 23372 \\ Korespondensi: diniislama@gmail.com
}

\begin{abstract}
ABSTRAK
Penelitian ini bertujuan untuk mengetahui pengaruh pemberian sumber nutrien berbeda pada media kultur terhadap kepadatan populasi dan laju pertumbuhan Daphnia sp. Rancangan percobaan yang digunakan adalah rancangan acak lengkap non faktorial dengan tiga perlakuan dan lima kali ulangan. Perlakuan yang diteliti adalah kultur Daphnia sp. dengan pemberian air endapan dedak fermentasi pada media (A), kultur Daphnia sp. dengan pemberian air endapan kotoran ayam pada media (B) dan kultur Daphnia sp. dengan pemberian bakteri merah pada media (C). Padat tebar awal Dahpnia sp. pada masing-masing wadah adalah 100 ind/l. Masa pemeliharaan Daphnia sp. berlangsung selama 20 hari. Hasil penelitian menunjukkan bahwa pemberian sumber nutrien berbeda pada media kultur berpengaruh nyata terhadap kepadatan populasi dan laju pertumbuhan Daphnia sp. Kepadatan populasi dan laju pertumbuhan Daphnia sp. tertinggi diperoleh pada perlakuan pemberian bakteri merah dalam media kultur (C) yaitu $1271.8 \mathrm{ind} / \mathrm{l}$ dan $0,14 \mathrm{ind} / \mathrm{l} / \mathrm{hari}$.
\end{abstract}

Kata Kunci : Bakteri merah, Dahpnia sp., dedak, kotoran ayam, pertumbuhan populasi

\begin{abstract}
This study aimed to examine the effect of different nutrient resources in culture media on population density and growth rate of Daphnia sp. The experiment design was used completely randomized design with four treatments and five replications. The treatments studied were Daphnia sp. culture with giving of fermented bran sediment water in media (A), Daphnia sp. culture with giving of chicken manure sediment water in media and Daphnia sp. culture with giving of red bacteria in media. Daphnia sp. stocking density was 100 ind/l. The culture period of Daphnia sp. was 20 days. The result showed that giving of different nutrient resources in culture media had significant effect on population density and growth rate of daphnia sp. Highest population density of Daphnia sp. and highest growth rate of daphnia sp. were obtained in treatment of C (1271.8 ind/l and $0,14 \mathrm{ind} / \mathrm{l} / \mathrm{day})$.
\end{abstract}

Keyword : Chicken manure, Dahpnia sp., population growth, red bacteria, rice bran fermented

\footnotetext{
${ }^{1}$ Program Studi Teknologi Produksi Benih dan Pakan Ikan, Politeknik Indonesia Venezuela (Poliven) Korespondensi: Politeknik Indonesia Venezuela (Poliven), Jln. Bandara Sultan Iskandar Muda km 12, Blang Bintang, Aceh Besar, Aceh 23372, Telp: +62 85260378145, email: diniislama@ gmail.com
} 


\section{PENDAHULUAN}

Dalam sektor budidaya perikanan, penggunaan pakan alami (live feeder) merupakan faktor penting yang harus diperhatikan dalam menunjang keberhasilan kegiatan pembenihan ikan. Hal ini dikarenakan pakan alami yang berkualitas dan kontinu sangat diperlukan dalam jumlah yang cukup, mengingat nutrisi utama dari pakan alami sangat dibutuhkan untuk pertumbuhan larva. Daphnia sp. adalah salah satu jenis pakan alami yang potensial untuk dikembangkan guna memenuhi ketersediaan pakan alami yang sesuai bagi kebutuhan larva ikan.

Daphnia sp. kedalam kelas Crustacea atau kelompok udang-udangan kecil yang bersifat non selective filter feeder, mudah dikultur, waktu panen cepat dan dapat diperkaya dengan bahan-bahan tertentu. Di alam, Daphnia sp. mengkonsumsi pakan berupa bakteri, fitoplankton, ciliata, dan detritus (Noerdjito, 2003). Daphnia sp. digunakan sebagai sumber pakan alami bagi larva ikan karena memiliki beberapa keunggulan yaitu kandungan nutrisi yang tinggi, ukuranya sesuai dengan bukaan mulut larva ikan, dan dapat dibudidayakan secara massal, sehingga produksinya dapat tersedia dalam jumlah mencukupi (Rachman, 2012).

Dewasa ini, Daphnia sp. sudah mulai dibudidayakan oleh pembudidaya di beberapa daerah di Indonesia guna memenuhi kebutuhan pakan alami pada kegiatan pembenihan ikan. Di Aceh, produktifitas Daphnia sp. masih sangat minim jika dibandingkan dengan pertumbuhan pantipanti pembenihan ikan yang semakin meningkat setiap tahunnya. Hal ini disebabkan oleh beberapa faktor, diantaranya adalah teknologi (teknik kultur) dan sumber nutrien yang tersedia pada media kultur Daphnia sp. belum memadai untuk menunjang pertumbuhannya, sehingga produktifitasnya masih belum optimal. Kebutuhan Daphnia sp. sebagian besar masih dipenuhi dari menangkap di alam dan didatangkan dari pulau jawa dalam bentuk Daphnia sp. beku. Oleh karena itu, produktifitas pakan alami terus diupayakan agar lebih optimal mengingat keberadaannya di alam tidak selalu tersedia. Salah satunya adalah dengan penambahan berbagai sumber nutrien ke dalam media kultur guna memacu tumbuhnya berbagai jenis organisme lain yang dapat dimanfaatkan oleh Daphnia sp. sebagai pakan. Menurut Pennak (1989), dalam pertumbuhannya Daphnia sp. memerlukan nutrisi yang berasal dari berbagai sumber, diantarannya dari bahan organik tersuspensi dan bakteri yang diperoleh dari pupuk yang ditambahkan kedalam media kultur. Pada penelitian ini, digunakan beberapa bahan organik sebagai sumber nutrien dalam kultur Daphnia sp. seperti kotoran ayam, dedak dan bakteri merah. Di air, kotoran ayam merupakan bahan organik dan juga merupakan media tempat tumbuh fitoplankton dan bakteri, yang ketiganya dapat dimanfaatkan sebagai pakan Daphnia sp. (Jusadi et. al., 2005). Pemberian dedak pada media kultur juga mampu meningkatkan populasi Daphnia sp., dimana hasil penelitian Sitohang (2012) menunjukkan bahwa pemberian dedak hasil fermentasi ragi sebesar $125 \mathrm{mg} / \mathrm{L}$ mampu menghasilkan pertumbuhan populasi Daphnia sp. tertinggi (puncak populasi) pada masa kultur 12 hari sebanyak $177 \mathrm{ind} / \mathrm{L}$.

Ketersediaan bahan organik pada media kultur berfungsi sebagai sumber nutrisi bagi pertumbuhan Daphnia sp. Proses penguraian (dekomposisi) nutrien yang ditambahkan dalam media kultur akan menumbuhkan bakteri yang pada akhirnya juga akan dimanfaatkan oleh Daphnia sp. sebagai pakan. Penelitian ini bertujuan untuk mengetahui efektivitas pemberian sumber nutrien berbeda pada media kultur terhadap kepadatan populasi dan laju pertumbuhan Daphnia sp. Dengan adanya penelitian ini, diharapkan mampu memberikan informasi terkait media budidaya Daphnia sp. yang efektif, sehingga kebutuhan pakan alami pada kegiatan pembenihan ikan dapat terpenuhi. 


\section{METODE PENELITIAN}

\section{Rancangan Penelitian}

Penelitian ini dilaksanakan pada bulan September sampai dengan Oktober 2017 di Laboratorium Pembenihan dan Produksi Pakan Ikan pada Program Studi Teknologi Produksi Benih dan Pakan Ikan, Poliven. Rancangan percobaan yang digunakan adalah Rancangan Acak Lengkap (RAL) non faktorial dengan tiga perlakuan dan lima kali ulangan. Perlakuan yang diteliti adalah kultur Daphnia sp. dengan pemberian air endapan dedak fermentasi pada media (A), kultur Daphnia sp. dengan pemberian air endapan kotoran ayam pada media (B) dan kultur Daphnia sp. dengan pemberian bakteri merah pada media (C).

\section{Prosedur Penelitian}

Wadah penelitian yang digunakan untuk budidaya Daphnia sp. adalah toples plastik dengan volume $5 \mathrm{~L}$ sebanyak 15 buah. Persiapan wadah dilakukan terlebih dahulu dengan cara mencuci wadah menggunakan air hingga bersih, kemudian dijemur selama 24 jam. Wadah yang telah bersih selanjutnya diisi air sebanyak 2 L. Tempat kultur dilengkapi dengan selang aerasi dan batu aerasi yang telah dicuci bersih dan dikeringkan selama satu hari. Toples yang telah diisi air kemudian dibiarkan selama 24 jam dan diaerasi sebelum penebaran.

Sampel Daphnia sp. yang digunakan diperoleh dari Balai Perikanan Budidaya Air Payau (BPBAP) Ujung Batee, Aceh Besar. Pemeliharaan Dahpnia sp. dilakukan dengan menambahkan air endapan dedak fermentasi, air endapan kotoran ayam dan bakteri merah ke dalam media kultur. Air endapan kotoran ayam dan dedak fermentasi disaring terlebih dahulu sebelum dimasukkan ke dalam wadah. Dahpnia sp. ditebar ke dalam setiap wadah dengan padat tebar awal 100 ind/l. Selanjutnya, pemeliharaan dilakukan selama 20 hari. Air endapan dedak, kotoran ayam dan bakteri merah diberikan 3 kali sehari yaitu pada pukul 08.00 WIB, pukul $12.00 \mathrm{WIB}$, dan pukul 16.00 WIB pada media pemeliharaan Daphnia sp. sebanyak $5 \mathrm{ml} / \mathrm{l}$ setiap pemberian pakan (Suryaningsih, 2006 dalam Mubarak et al., 2009).

Pengamatan populasi Daphnia sp. dari setiap perlakuan percobaan dilakukan pada pukul 09.00-10.00 WIB, dengan interval waktu dua hari sekali selama 20 hari pemeliharaan. Pengamatan pertumbuhan populasi dilakukan dengan teknik sampling, yaitu dengan mengambil contoh sampel dari masing-masing perlakuan media kultur Dahpnia sp. dengan menggunakan gelas ukur sebanyak lima kali ulangan. Pada saat pengambilan sampel, media kultur diaerasi kuat terlebih dahulu agar Daphnia sp. dapat menyebar secara merata di dalam wadah.

\section{Parameter Uji}

\section{Kepadatan Populasi Daphnia sp.}

Perhitungan populasi Daphnia sp. dilakukan dengan mengambil sampel dari masing-masing media kultur sebanyak $20 \mathrm{ml}$. Perhitungan dilakukan dalam cawan petri, dimana perhitungan jumlah individu dilakukan sebanyak lima kali ulangan dan hasilnya dirata-ratakan. Hasil rata-rata perhitungan banyaknya individu Daphnia sp. dikonversikan dalam jumlah ind/l dengan rumus menurut Rahayu dan Piranti (2009) sebagai berikut :

$$
a=b \times p / q
$$

Keterangan :

$\mathrm{a}=$ Jumlah individu Daphnia $s p$. pada media kultur (ind/L)

$\mathrm{b}=$ Rata-rata jumlah Daphnia sp. dari ulangan perhitungan

$\mathrm{p}=$ volume media kultur $(\mathrm{L})$

$\mathrm{q}=$ volume botol sampel $(\mathrm{L})$

\section{Puncak Populasi}

Pengamatan puncak populasi setiap perlakuan dihitung mulai dari awal 
pertumbuhan hingga mencapai jumlah individu tertinggi dengan pencapaian waktu (hari) tertentu.

\section{Laju Pertumbuhan}

Menurut Kusumaryanto (1988), pertumbuhan populasi Daphnia dihitung pada hari pertama hingga mencapai puncak populasi dengan menggunakan rumus :

$$
\mathrm{Ln} \mathrm{Nt}=\mathrm{Ln} \mathrm{No}+\mathrm{g} \cdot \mathrm{t}
$$

\section{Keterangan:}

$\mathrm{g}=$ Laju pertumbuhan (ind/l/hari)

No $=$ Jumlah individu pada awal percobaan (ind/L)

$\mathrm{Nt}=$ Jumlah individu pada puncak populasi (ind/L)

$\mathrm{t}=$ Waktu mencapai puncak populasi.

\section{Kualitas air}

Pengamatan kualitas air dilakukan untuk mengetahui gambaran kualitas air secara umum selama pemeliharaan (Effendi, 2003). Parameter kualitas air yang diamati hanya secara umum yaitu parameter kimia berupa $\mathrm{pH}$ dan oksigen terlarut (DO), sedangkan untuk parameter fisika berupa pengukuran suhu. Pengamatan kualitas air dilakukan setiap sehari sekali.

\section{Analisis Data}

Data yang diperoleh dianalisis menggunakan program microsoft excel 2010 dan SPSS 19.0, yang meliputi Analisis Ragam (ANOVA). Apabila berpengaruh nyata, untuk melihat perbedaan antar perlakuan akan diuji lanjut menggunakan uji Duncan dengan selang kepercayaan 95\%. Sedangkan data kualitas air yang meliputi parameter fisikakimia perairan akan dianalisis secara deskriptif.

\section{HASIL DAN PEMBAHASAN}

\section{Kepadatan Populasi Daphnia sp.}

Dari hasil pengamatan terhadap pertumbuhan populasi Daphnia sp. yang dipelihara pada media kultur dengan pemberian sumber nutrien berbeda berupa dedak fermentasi, kotoran ayam dan bakteri merah menunjukkan adanya peningkatan pertumbuhan populasi dengan pola yang relatif sama. Pola pertumbuhan populasi membentuk kurva sigmoid yang terdiri dari fase adaptasi, fase ekponensial/logaritma, fase stasioner dan fase kematian. Menurut Zahidah et al., (2012), pertumbuhan Daphnia sp. terdiri dari fase adaptasi, fase eksponensial, fase stationer dan fase kematian. Hasil pengamatan pertumbuhan populasi Daphnia sp. selama 20 hari dengan interval waktu perhitungan 2 hari sekali disajikan pada Gambar 1.

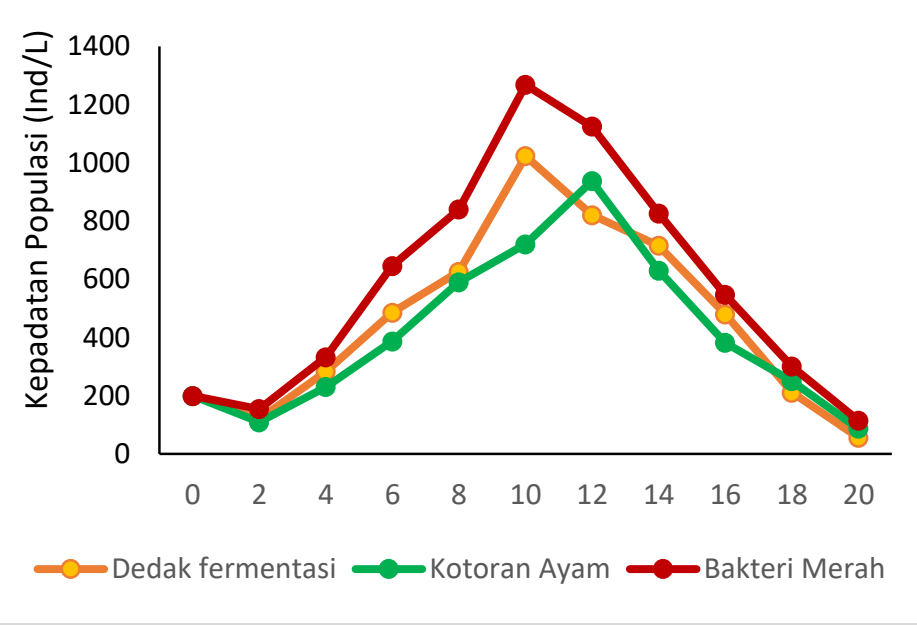

Gambar 1. Kurva Pertumbuhan Populasi Daphnia sp. Selama Masa Pemeliharaan.

Fase adaptasi adalah tahap penyesuaian Daphnia sp. terhadap media kultur, dimana pada penelitian ini fase adaptasi untuk ketiga perlakuan terjadi pada hari yang sama yaitu hari ke-0 sampai dengan hari ke-2. Menurut Nailulmuna (2017), faktor yang mempengaruhi proses adaptasi meliputi penyesuaian terhadap lingkungan maupun penyesuaian terhadap kandungan bahan 
organik yang terdapat pada media kultur Daphnia sp. Selanjutnya, Daphnia sp. mengalami fase eksponensial yaitu fase peningkatan jumlah individu Daphnia sp. menjadi beberapa kali lipat dalam jangka waktu tertentu karena adanya siklus reproduksi (Zahidah et al., 2012). Pada fase eksponensial pertumbuhan terjadi sampai puncak populasi. Fase eksponensial pada perlakuan pemberian bakteri merah dan air endapan dedak fermentasi terjadi tiga kali yaitu pada hari ke-4, hari ke-6 dan hari ke-8. Sedangkan pada perlakuan pemberian air endapan kotoran ayam terjadi empat kali yaitu pada hari ke-4, hari ke-6, hari ke-8 dan hari ke-10. Hal ini sesuai dengan penelitian Mubarak (2009), bahwa setelah hari ke-2 populasi Daphnia sp. meningkat karena adanya proses reproduksi yang mulai terjadi secara partenogenesis yang menghasilkan anakan baru dengan cepat. Selanjutnya, fase stasioner merupakan fase puncak populasi (Izzah et al., 2014). Fase stasioner tertinggi untuk perlakuan pemberian bakteri merah dan air endapan dedak fermentasi terjadi pada hari ke-10 yaitu 1.042,71 ind/l dan 1.271,8 ind/l. Pada perlakuan pemberian air endapan kotoran ayam, fase stasioner terjadi pada hari ke-12 yaitu 937,36 ind/L. Pencapaian populasi menjadi lebih cepat karena didukung oleh pakan yang mengandung nutrisi yang optimal untuk pertumbuhannya (Chilmawati dan Suminto, 2010). Selanjutnya, semua perlakuan mengalami fase terakhir yaitu fase kematian. Fase kematian ditandai dengan terjadinya penurunan jumlah populasi Daphnia sp. secara drastis dalam waktu singkat yang menggambarkan adanya kematian masal Daphnia sp. dalam media budidaya. Hal ini diduga karena pada saat populasi Daphnia sp. mencapai puncak, maka tingkat kepadatan individu Daphnia sp. mencapai klimaks, sehingga nutrisi yang tersedia pada media kultur menurun. Menurut Firdaus (2004), bahwa penyebab terjadinya penurunan populasi Daphnia sp. setelah puncak populasi disebabkan karena semakin berkurangnya bahan organik terlarut.

\section{Hasil Analisis Ragam (ANOVA)} menunjukkan bahwa pemberian sumber nutrien berbeda pada media kultur berpengaruh nyata terhadap kepadatan populasi Daphnia sp. pada puncak populasi $(\mathrm{P}<0,05)$. Nilai rata-rata kepadatan Daphnia sp. pada puncak populasi dan hari puncak populasi disajikan pada Tabel 1 .

Tabel 1. Nilai rata-rata kepadatan Daphnia sp. pada puncak populasi dan hari puncak populasi

\begin{tabular}{ccc}
\hline Perlakuan & $\begin{array}{c}\text { Kepadatan rata-rata } \\
\text { (ind/l) }\end{array}$ & $\begin{array}{c}\text { Puncak Populasi } \\
\text { Pengamatan ke- }\end{array}$ \\
\hline A & $1042.71 \pm 144.11^{\mathrm{a}}$ & 10 \\
B & $937.36 \pm 81,05^{\mathrm{a}}$ & 12 \\
C & $1271.8 \pm 128.07^{\mathrm{b}}$ & 10 \\
\hline
\end{tabular}

Ket : Angka yang diikuti oleh huruf yang sama pada kolom yang sama tidak berbeda nyata pada taraf peluang $5 \%$ (Uji Duncan).

Dari Tabel diatas dapat dilihat bahwa kepadatan populasi Daphnia sp. pada puncak populasi dengan media kultur yang ditambahkan sumber nutrien berupa bakteri merah berbeda nyata dengan perlakuan pemberian air endapan dedak fermentasi dan air endapan kotoran ayam, namun tidak berbeda nyata antara perlakuan pemberian air endapan dedak fermentasi dengan air endapan kotoran ayam. Pemberian sumber nutrien berupa bakteri merah pada media kultur menghasilkan kepadatan populasi yang lebih tinggi dibandingkan dengan dua perlakuan lainnya, dimana puncak populasi terjadi pada hari ke-10. Hasil ini sesuai dengan penelitian Jusadi (2005), dimana umur sampai puncak populasi Daphnia sp. pada pemberian makanan secara tidak langsung (dengan penambahan makanan dari luar wadah) antara 10 - 22 hari dibandingkan secara langsung yang hanya selama 7 - 12 hari.

Perbedaan kepadatan populasi pada puncak populasi diduga karena adanya perbedaan jenis pupuk yang digunakan dan perbedaan jumlah nutrisi yang terkandung pada masing-masing pupuk. Menurut Pursetyo et al. (2011), kualitas dan jumlah pupuk yang diberikan pada media 
berpengaruh terhadap jumlah makanan yang ada pada media kultur. Ketersediaan jenis pakan yang sesuai dalam jumlah yang melimpah dapat memenuhi kebutuhan Daphnia sp. untuk tumbuh dan berkembang biak secara maksimal. Oleh karena itu, kandungan nutrisi pada bakteri merah diduga mampu memenuhi kebutuhan Daphnia sp untuk tumbuh dan berkembang biak, sehingga meningkatkan populasi Daphnia sp. lebih banyak dibandingkan dua perlakuan lainnya.. Selain itu, pola pertumbuhan Daphnia sp. juga dipengaruhi oleh beberapa faktor antara lain kondisi fisik perairan, jenis pakan, dan konsentrasi pakan. apabila faktor tersebut mendukung, maka laju pertumbuhan Daphnia sp. akan berlangsung lebih cepat dan menghasilkan puncak populasi yang lebih banyak (Noerdjito, 2004).

\section{Laju Pertumbuhan}

Hasil Analisis Ragam (ANOVA) menunjukkan bahwa pemberian sumber nutrien berbeda pada media kultur berpengaruh nyata terhadap laju pertumbuhan Daphnia sp. $(\mathrm{P}<0,05)$. Nilai rata-rata laju pertumbuhan Daphnia sp. selama masa pemeliharaan disajikan pada Gambar 2.

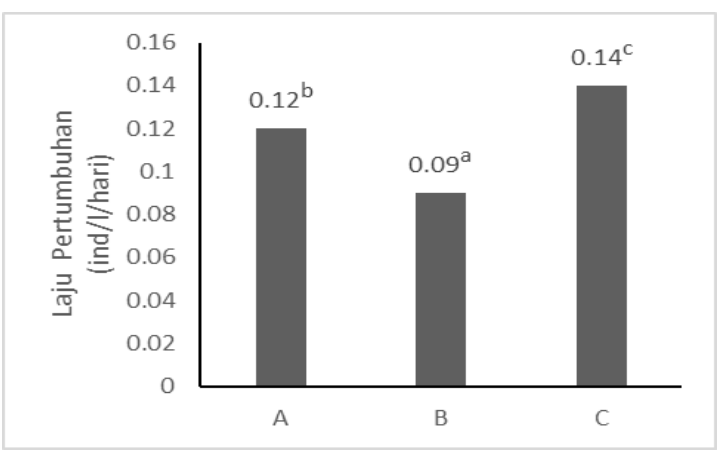

Gambar 2. Laju Pertumbuhan Daphnia sp. Selama Masa Pemeliharaan.

Berdasarkan hasil uji lanjut Duncan, laju pertumbuhan Daphnia sp. yang ditambahkan bakteri merah pada media kultur berbeda nyata dengan perlakuan pemberian air endapan dedak fermentasi dan air endapan kotoran ayam. Pemberian sumber nutrien berupa bakteri merah pada media kultur menghasilkan laju pertumbuhan yang lebih tinggi dibandingkan dengan dua perlakuan lainnya. Pemberian sumber nutrien berupa bakteri merah diduga lebih efektif dimanfaatkan oleh Daphnia sp. sebagai makanannya karena ukuran partikelnya yang lebih kecil, memiliki kepadatan bakteri dan nutrisi yang tinggi, sehingga mampu menunjang pertumbuhannya. Menurut Pennak (1989), alga dan protozoa merupakan makanan utama Daphnia sp., bakteri dan fungi menduduki urutan teratas dari nilai nutrisinya, dengan jenis makanan ini Daphnia sp. dapat hidup dan berkembang biak. Selain itu, bakteri merah juga dapat digunakan langsung oleh Daphnia sp. sebagai makanan, sedangkan kotoran ayam dan dedak fermentasi berperan sebagai pupuk yang harus diuraikan terlebih dahulu oleh bakteri menjadi bahan organik agar dapat merangsang pertumbuhan fitoplankton yang merupakan makanan Daphnia sp., sehingga meskipun juga mampu meningkatkan laju pertumbuhannya, namun cenderung lebih rendah dibandingkan perlakuan pemberian bakteri merah pada media kultur. Menurut Zahidah (2012), Daphnia sp. dapat memanfaatkan berbagai macam jenis bakteri, mikroalga dan detritus sebagai sumber nutrient utamanya. Daphnia sp. juga merupakan hewan filter feeder yang mengkonsumsi pakan berupa bakteri, fitoplankton, ciliata, dan detritus (Noerdjito, 2004).

Faktor lain yang mempengaruhi pertumbuhan populasi Daphnia sp. yaitu fisika kimia perairan seperti suhu, $\mathrm{pH}$, dan oksigen terlarut. Dalam penelitian ini, kualitas air pemeliharaan berada pada kisaran optimal untuk pemeliharaan Daphnia sp. sesuai kelayakan menurut pustaka. Nilai parameter kualitas air selama pemeliharaan Daphnia sp. disajikan pada Tabel 2. 
Tabel 2. Nilai parameter kualitas air selama pemeliharaan Daphnia sp.

\begin{tabular}{cccc}
\hline \multirow{2}{*}{ Perlakuan } & \multicolumn{3}{c}{ Parameter) } \\
\cline { 2 - 4 } & $\begin{array}{c}\text { Suhu } \\
\left({ }^{0} \mathrm{C}\right)\end{array}$ & $\mathrm{pH}$ & $\mathrm{DO}(\mathrm{mg} / \mathrm{l})$ \\
\hline $\mathrm{A}$ & $26-28$ & $7-7,33$ & $6,7-7,2$ \\
$\mathrm{~B}$ & $26-28$ & $6,7-7,5$ & $5,9-6,8$ \\
$\mathrm{C}$ & $26-28$ & $7-7,5$ & $6,8-7,5$ \\
Kelayakan & & & \\
Menurut & $22-31^{\circ} \mathrm{C}^{*}$ & $6,9-9,5$ & $>3 \mathrm{mg} / \mathrm{l}^{*}$ \\
Pustaka & & & \\
\hline Keterangan: & *(Radini, 2006) & \\
& $* *$ (Mufidah, 2009)
\end{tabular}

\section{KESIMPULAN}

Berdasarkan hasil penelitian dapat disimpulkan bahwa pemberian sumber nutrien berbeda pada media kultur berpengaruh nyata terhadap kepadatan populasi dan laju pertumbuhan Daphnia sp. Kepadatan populasi dan laju pertumbuhan Daphnia sp. tertinggi diperoleh pada perlakuan pemberian bakteri merah dalam media kultur (C) yaitu 1271.8 ind/l dan 0,14 ind/l/hari.

\section{DAFTAR PUSTAKA}

Chilmawati, D., Suminto. 2010. Pengaruh penggunaan ragi roti, vitamin b12 dan vitamin $\mathrm{c}$ sebagai bahan pengkaya pakan terhadap penambahan populasi Brancionus plicatis. Jurnal perikanan. 5 (2) : 47-53.

Effendi, H. 2003. Kualitas Air. Penerbit Kanasius. Yogyakarta.

Firdaus, M. 2004. Pengaruh Beberapa Cara Budidaya Terhadap Pertumbuhan Populasi Daphnia Sp. [Skripsi]. Program Studi Budidaya Perairan, Fakultas Perikanan dan Ilmu Kelautan Institut Pertanian Bogor. 47 hlm.

Izzah, N. Suminto, V.E. Herawati. 2014. Pengaruh bahan organik bekatul dan bungkil kelapa melalui proses fermentasi bakteri probiotik terhadap pola pertumbuhan dan produksi biomassa Daphnia sp. Journal of
Aquaculture Management and Technology. 3(2): 44-52.

Jusadi, D., Sulasingkin, D., Ing Mokoginta. 2005. Pengaruh konsentrasi ragi yang berbeda terhadap pertumbuhan populasi Daphnia sp. Departemen Budidaya Perairan, Fakultas Perikanan dan Ilmu Kelautan, Institut Pertanian Bogor. Jurnal Ilmu-ilmu Perairan dan Perikanan Indonesia. 12 (1): 17-21.

Kusumaryanto. 1988. Zoologi Invertebrata. Prisma Press. Bandung.

Mubarak, A.S. 2009. Pemberian dolomit pada kultur Daphnia sp. sistem daily feeding pada populasi Daphnia sp. dan kestabilan kualitas air. Jurnal Ilmiah Perikanan dan Kelautan. 1(1): 67-72.

Mufidah, N. B. W. 2009. Pengkayaan Daphnia Spp. dengan viterna terhadap kelangsungan hidup dan pertumbuhan larva ikan lele dumbo (Clarias gariepinus). Jurnal Ilmiah Perikanan dan Kelautan. 1 (1): 59-65.

Nailulmuna, Z., Pinandoyo, Herawati, V.E. 2017. Pengaruh pemberian fermentasi kotoran ayam roti afkir dan ampas tahu dalam media kultur massal terhadap pertumbuhan dan kandungan nutrisi Daphnia sp. Jurnal Bioma. 19 (1): 47 57.

Noerdjito, D. R. 2003. Optimasi suhu, pH, serta jumlah dan jenis pakan pada kultur Daphnia sp. Sekolah Ilmu dan Teknologi Hayati ITB. Bandung.

Pennak. 1989. The Invertebrata A Manual for The Use Of Student. Cambridge At The University Press. Cambridge.

Pursetyo, K. T., Woro. H. S., Shofy, M. A,. 2011. pengaruh pemupukan ulang kotoran ayam kering terhadap populasi cacing tubifex . Jurnal Ilmiah Perikanan dan Kelautan. 3(2): 177-182.

Rachman, E. 2012. Pengaruh urine kelinci hamil dalam media kultur terhadap kontribusi anak setiap kelompok umur Daphnia Sp. Jurnal Perikanan dan Kelautan. 3(3): 23-40.

Radini. D, 2006. Optimasi Suhu, pH Serta Jenis Pakan Pada Kultur Daphnia sp. 
Sekolah Tinggi Ilmu dan Teknologi Hayati. Bandung.

Rahayu, D.R.U.S., A. S. Piranti. 2009. Pemanfaatan limbah cair tahu untuk produksi ephipium daphnia (Daphnia sp). Makalah Prosiding Seminar Nasional Biologi "Peran Biosistematika dalam Pengelolaan Sumberdaya Hayati Indonesia" tanggal 12 Desember 2009 di Fak. Biologi Universitas Jenderal Soedirman Purwokerto

Sitohang, R. V. Titin, H. dan Walim, L. 2012. Pengaruh pemberian dedak padi hasil fermentasi ragi (Saccharomyces cerevisiae) terhadap pertumbuhan biomassa Daphnia sp. Jurnal Perikanan dan kelautan. Unpad. 3(1). 65-72.

Zahidah, W. Gunawan, dan Subhan, U. 2012. Pertumbuhan populasi Daphnia sp. yang diberi pupuk limbah budidaya keramba jarring apung (KJA) di waduk cirata yang telah di fermentasi EM4. Jurnal Akuatika. 3 (1) : 84-94. 